\title{
Concordance between Ephemeroptera and Trichoptera assemblage in streams from Cerrado - Amazonia transition
}

\author{
Leandro Juen $^{1 *}$, Denis S. Nogueira ${ }^{2}$, Yulie Shimano ${ }^{3}$, Ludgero C. Galli Vieira ${ }^{4}$
}

and Helena S. R. Cabette ${ }^{5}$

${ }^{1}$ Instituto de Ciências Biológicas, Universidade Federal do Pará, Rua Augusto Correia, no 1 Bairro Guamá, 66.075-110 Belém, PA, Brazil

2 Programa de Pós-Graduação em Ecologia e Evolução, Universidade Federal de Goiás, Caixa Postal 24.241, 74.690-970 Goiânia, GO, Brazil

${ }^{3}$ Programa de Pós-Graduação em Zoologia, Universidade Federal do Pará, Rua Augusto Correia, no 1 Bairro Guamá, 66.075-110 Belém, PA, Brazil

${ }^{4}$ Universidade de Brasília, Campus de Planaltina (FUP), Área Universitária 1, Vila Nossa Senhora de Fátima, 73.340-710 Planaltina, DF, Brazil

5 Departamento de Ciências Biológicas, Universidade do Estado de Mato Grosso, Caixa Postal 08, 78.690-000 Nova Xavantina, Mato Grosso, Brazil

Received 11 December 2012; Accepted 22 April 2013

\begin{abstract}
We evaluated the concordance between assemblages of Ephemeroptera and Trichoptera to verify if they respond similarly to environmental gradients in the basin of Suiá-Missu river in Mato Grosso, central Brazil. We tested the predictions that: (i) the distributional pattern of mayfly and caddisfly larvae is concordant along the spatial and (ii) environmental variation along the basin, and if (iii) taxa are concordant between themselves along the seasons and with the environmental gradients disregarding the seasons of the year. We found a concordance between species composition of mayfly and caddisfly in fall-water and rainy period, when analyzed separately by each season. The concordance between environmental variables and the two taxa analyzed separately also was concordant, but only on the fall-water season. Finally, we found congruence when both analyzed groups disregarded the temporal effect, but it was less representative than when we consider the seasons variation. Our results suggest that the hydrological cycle could be a driver of changes in species composition of mayflies and caddisflies.
\end{abstract}

Key words: Biotic patterns / macroinvertebrates / aquatic insects / temporal variations / environmental gradient

\section{Introduction}

The major goal in ecology is to understand how parameters of biological communities (abundance, richness, and composition) respond to environmental variations (De Chaine and Martin, 2005; Bini et al., 2007). Studies on organism's distributions in nature have revealed recurring patterns along environmental gradients, such as changes in community structures and species composition; latitudinal congruence of diversity can arise even in unrelated groups from all biogeographical regions around the world (Heino, 2002; Bini et al., 2007).

\footnotetext{
*Corresponding author: leandrojuen@ufpa.br
}

Similar spatial and temporal pattern among two or more taxa in relation to environmental gradient is called community concordance (Bowman et al., 2008). Concordant patterns may also represent common preferences and adaptations, biotic interactions, covariance of assemblage responses to determinant environmental properties or even historical factors related to habitat colonization and evolution (Bini et al., 2008). Thus, studies of community concordance can be used to evaluate patterns in biological communities, biodiversity, as a measure of responses to environmental changes and the placement of different taxa in a single surrogate group (Cameron et al., 2008). Some authors found concordance between aquatic organisms with similar dispersal ability, similar sizes and habits requirements (Heino, 2010), among 
macroinvertebrates, fish and algae (Monaghan and Soares, 2010), between fish and birds (Paszkowski and Tonn, 2000) and among phytoplankton, zooplankton, macroinvertebrates, and fish (Bowman et al., 2008).

The most important theories about energetic dynamics of rivers suggest that river sizes can produce concordance among several taxa, according to their functional adjusts along the River Continuum (Vannote et al., 1980). This information increases the power of hypothesis generalization and effectiveness in model building (Heino, 2010). In addition, certain groups may be surrogate for biodiversity assessment when analyzing responses to environmental changes in local and landscape scale and they can be used in monitoring programs to minimize costs when two or more groups respond similarly to environmental changes (Faith, 2003; Heino and Mykrä, 2006). However, there is evidence suggesting that the choice of indicators or surrogate groups may have limited value for studies of freshwater biodiversity due to divergent patterns or low concordance between communities (Heino et al., 2005; Heino, 2010), which often reflects differences in evolutive history among clades of aquatic organisms.

The insect orders Ephemeroptera (mayflies) and Trichoptera (caddisflies) occupy a wide range of habitats in lotic ecosystems, inhabiting several meso and microhabitats from small streams to large rivers (Wiggins and Mackay, 1978; Wiggins, 1996; Domínguez et al., 2006). The distribution of these insects is related to food availability, environmental variables and energy input along a watershed continuum (Vannote et al., 1980). In freshwater environments, mayflies and caddisflies are important links in food webs, also have similar body size range, and show high local species richness and abundance. These groups are widely studied and used in biomonitoring programs due to high sensitivity to pollutants and other environmental disturbances (Rosenberg and Resh, 1993).

Our goal was to evaluate the concordance between mayflies and caddisflies assemblages along an environmental gradient in Suiá-Missu river tributaries, Mato Grosso, Central Brazil. Specifically, following predictions of similar traits among several groups of Ephemeroptera and Trichoptera on tropical ecosystems we tested if (i) distributional pattern of mayfly and caddisfly larvae are concordant along the spatial and (ii) environmental variation along the basin, and if (iii) taxa are concordant between themselves and with the environmental variation along the seasons of the year.

\section{Methods}

\section{Study site}

Suiá-Missu river is the main tributary of the Xingu river, located in the transition zone between Cerrado and Amazon Forest, in Mato Grosso, central Brazil (between $11^{\circ} 15^{\prime}$ to $13^{\circ} 40^{\prime} \mathrm{S}$ and $53^{\circ} 15^{\prime}$ to $\left.51^{\circ} 15^{\prime} \mathrm{W}\right)$. Climate is seasonal tropical, with a dry (May-October) and rainy season (November-April). In Köppen climate classification, the major part of the region is Savanna $(A w)$, with microregions with monsoon subtype $(A m)$, and tropical rainy $(A)$. The rainfall annual mean is $1.370 \mathrm{~mm}$, and the monthly mean temperature varies between 32.7 and $17.0^{\circ} \mathrm{C}$ (Ratter et al., 1978).

The predominant economic activities are wood exploitation, rice and soybean monocultures, and extensive pasture for cattle (Riva et al., 2007). Recently, dams construction project to provide energy building have generated interest conflicts between conservationists and government priorities in middle Xingu River, in Pará State, despite their low-energy supply potential and probability of high sedimentation (Carvalho et al., 2004). The impact of dam construction on regional biodiversity is still understudied, but it is especially dangerous for aquatic organisms.

For evaluation of concordance among Ephemeroptera and Trichoptera, we selected 12 sampling sites encompassing several types of Cerrado vegetation in Suiá-Missu river and its tributaries (Fig. 1). The sampled streams ranged from 1st to 6th order, following Strahler (1957), and they varied in channel width, water flow, vegetation in riparian zone, and conservation status (see Fig. 1 for abbreviations). The substrata found in the sampling sites ranged from roots on banks, submerged vegetation, leaves, stems and twigs in pools and rapids, rocks, gravel and sand in lotic environments; and submerged macrophytes, roots and fine particulate organic matter, and silt in marshy environments (for details see Shimano et al., 2010; Nogueira et al., 2011).

\section{Data sampling}

We sampled insect larvae in dry (September 2007), rainy (December 2007), and fall-water (May 2008) seasons. We established $100 \mathrm{~m}$ transects in each one of 12 sampling sites, subdivided into 20 segments of $5 \mathrm{~m}$ following the methodology adapted from Juen and De Marco (2011). We sampled portions of substratum within each segment with a dip netting of $18 \mathrm{~cm}$ diameter and $0.025 \mathrm{~mm}$ mesh. By this method, the pseudo-sample unit is each $5 \mathrm{~m}$ segments of the $100 \mathrm{~m}$ transect, which are used to estimate species richness for each site. Taxonomic compositions are assessed by sum of species abundance in all subsamples (see details below).

We identified specimens using genus keys for Ephemeroptera (Domínguez et al., 2006) and Trichoptera (Angrisano and Korob, 2001; Pes et al., 2005). Afterwards, the species were morphospecied using phenotypic characteristics to distinguish the last larval stages within genus. The specimens were preserved in $85 \%$ alcohol and housed at the Coleção Zoobotânica "James Alexander Ratter" (CZNX), Universidade do Estado de Mato Grosso, Brazil.

Physicochemical data were sampled in three seasons, in the same transects used by insect larvae sampling. We recorded water temperature, $\mathrm{pH}$, turbidity, electrical conductivity, dissolved oxygen, depth, flow, total soluble solids, and redox potential using a multiparameter probe. 


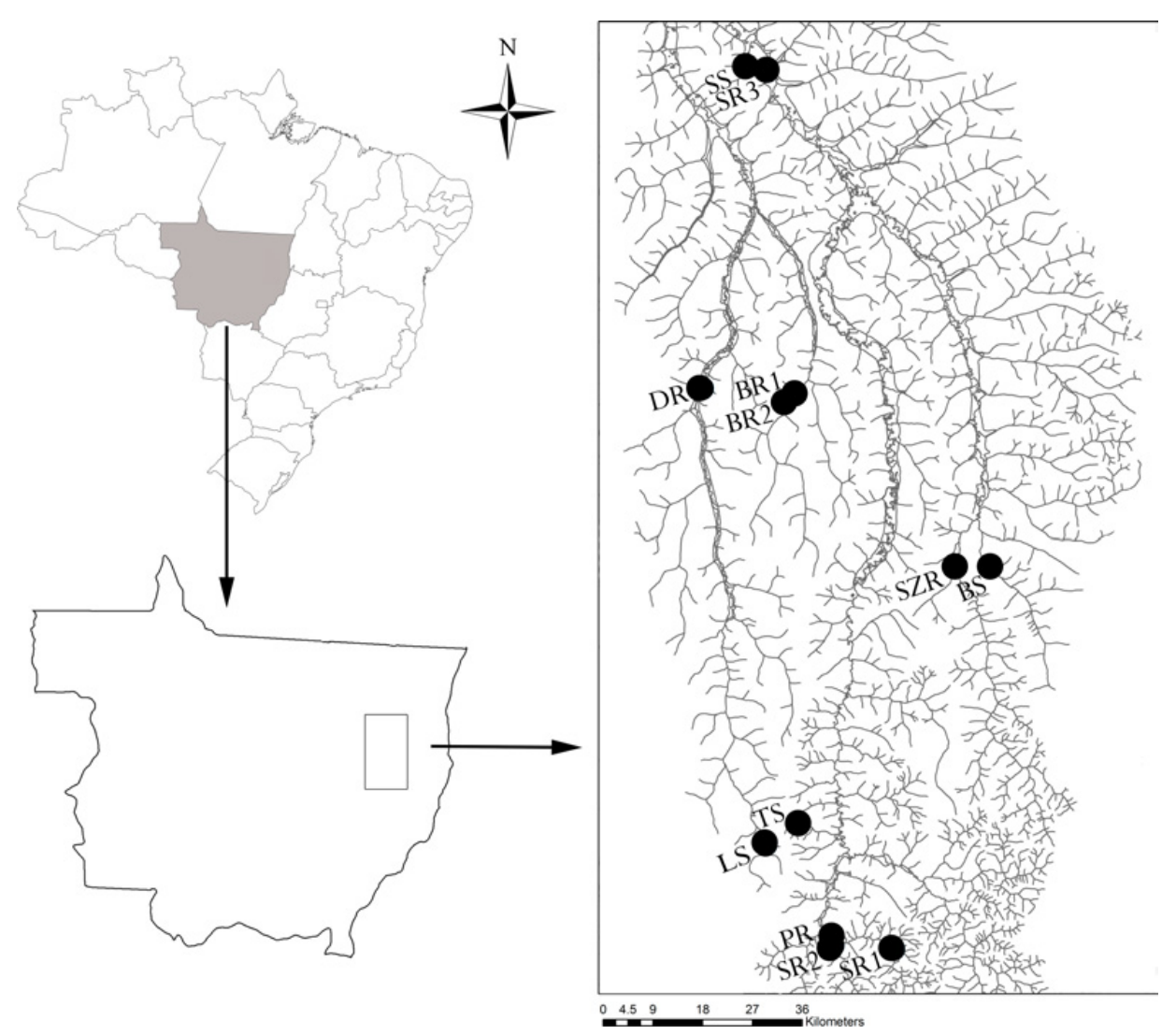

Fig. 1. Sampling sites of mayfly and caddisfly larvae in the Basin of Rio Suiá-Missu, Mato Grosso (SR1 = Suiá-Missu River; SR2 = Suiá-Missu River; SR3 = Suiá-Missu River; SS = Sucuri Stream; DR = Darro River; BR1 = Betis River; BR2=Betis River; $\mathrm{SZR}=$ Suiazinho River; TS = Transição Stream; PR = Piabanha River; LS = Lúcio Stream; and BS = Brejão Stream).

We measured concentrations of ammonium nitrate, nitrite, and phosphate ions with a portable spectrophotometer, and total hardness, $\mathrm{Ca}^{++}$and $\mathrm{Mg}^{++}$with 0.0002 M EDTA. Streams and rivers widths were measured with a tape-measure. We evaluated environmental integrity with Habitat Integrity Index-HII (Nessimian et al., 2008). This index is based on measurement of a series of parameters visually assessed related to land use, riparian zone conservation, streambed characteristics, and stream channel morphology related to margin and streamlet bed structure.

\section{Data analysis}

We used eight variables that were selected after we tested multicolinearity by correlation matrix (water temperature, $\mathrm{pH}$, turbidity, electrical conductivity, dissolved oxygen, depth, width, and HII). To reduce dimensionality in abiotic data, we used principal component analysis (PCA) based on the correlation matrix of environmental variables after log transformation (except for $\mathrm{pH}$ ) and standardization (Olden et al., 2001). Posteriorly, we used the Broken stick method (Jackson and Harvey, 1993) to select the number of axes for interpretation. Analysis was designed in $\mathrm{R}$ environment by using functions of vegan package (Oksanen et al., 2011). To test the significance of the groups (seasons) formed in PCA, we run an ANOVA for the two first PCA axis.

We estimated species richness for each insect order and for both orders combined with the nonparametric estimator first order jackknife by using EstimateS v.7.5.0 (Colwell, 2005). Then, we have an estimative for species richness for each order in studied seasons and for a combination of both orders, which were regressed against environmental gradients summarized in PCA axes. In addition, we tested species richness and abundance along seasons using non-parametric repeated measures Friedman ANOVA and pairwise comparisons for significant results were evaluated by using Wilcoxon matched pairs test for dependent samples (Zar, 1999).

We analyzed the structure of mayfly and caddisfly assemblages in relation to abiotic data using an indirect gradient analysis (Gauch, 1982). We used a detrended correspondence analysis (DCA) to summarize species composition (abundance) in different environments. Correspondence analysis was run with data of all streams sampled, after log transformation.

We evaluated the degree of concordance between species composition matrix and abiotic data using a Procrustean routine (Jackson, 1995). We performed this analysis with the scores of the first two axes of each ordination (DCA and PCA), since they contain most of the variability of original data. We perform this procedure 
Table 1. Environmental variables, loadings, eigenvalues and Broken-stick values of the first two axes of PCA. (Mean and SD in 36 measurements, three in each stream site).

\begin{tabular}{|c|c|c|c|c|c|c|c|c|}
\hline & \multicolumn{2}{|c|}{ Dry season } & \multicolumn{2}{|c|}{ Rainy season } & \multicolumn{2}{|c|}{ Fall-water season } & \multicolumn{2}{|c|}{ Loadings } \\
\hline & $\overline{\text { Mean }}$ & $\overline{\mathrm{SD}}$ & Mean & SD & Mean & SD & $\overline{\text { PCA } 1}$ & $\overline{\text { PCA } 2}$ \\
\hline$\overline{\mathrm{HII}}$ & 0.63 & 0.1 & 0.63 & 0.1 & 0.63 & 0.1 & -0.41 & -0.36 \\
\hline $\mathrm{pH}$ & 5.5 & 0.41 & 5.03 & 0.2 & 4.89 & 0.47 & -0.2 & 0.08 \\
\hline Electrical conductivity & 0.72 & 0.21 & 0.78 & 0.26 & 0.68 & 0.37 & 0.03 & 0.32 \\
\hline Turbidity & 7.93 & 8.46 & 5.97 & 6.33 & 62.02 & 27.56 & 0.63 & -0.77 \\
\hline Water temperature & 26.95 & 3.36 & 27.34 & 1.41 & 24.13 & 0.98 & -0.61 & 0.17 \\
\hline Dissolved oxygen & 5.97 & 2.26 & 6.23 & 1.8 & 7.53 & 2.58 & -0.11 & -0.38 \\
\hline Channel width & 33.51 & 42.85 & 33.48 & 43.15 & 34.58 & 44.06 & -0.89 & -0.41 \\
\hline Depth & 1.46 & 1.4 & 1.45 & 1.69 & 1.28 & 1.11 & -0.57 & -0.53 \\
\hline
\end{tabular}

in different ways to account for all environmental variability in our dataset. Firstly, we evaluated spatial concordance of the order within each season (dry, rainy, and fall-water seasons). Afterwards, we analyzed the concordance between a dataset composed by both orders against environmental seasonality in three separate seasons. Finally, we analyzed the temporal concordance using seasons as replicate. The test statistic $\left(\mathrm{m}^{2}\right)$ measures how divergent ordination patterns of the two datasets are, and the significance is then tested after 10000 permutations. The Procrustes analysis was performed in $\mathrm{R}$ software (version 2.10.1) (R Development Core Team, 2011).

\section{Results}

\section{Environmental variables}

The first two PCA axes explain about $75.41 \%$ of the variation in environmental data (Table 1). PC1 explained $45.42 \%$ of environmental variation and was negatively correlated with water temperature, channel width and depth, and positively related to turbidity. PC2 explained $29.99 \%$ of environmental data and was negatively correlated with turbidity. There was a cluster of samples from fall-water season (at the bottom of the figure), whereas those of dry and rainy season did not form a cluster (Fig. 2). However, the ANOVA showed that there was a difference between fall-water samples and the remaining ones in the 2 nd axis $\left(F_{(2,33)}=9.878 ; P<0.001\right)$.

\section{Assemblage structure}

We sampled an overall of 2223 larvae, 1356 were mayflies (Appendix 1) and 867 caddisflies (Appendix 2). The mayflies sampled belonged to seven families, 31 genera, and 42 species/morphospecies. The highest abundance was recorded at fall-water, with 529 larvae, with $44.1 \pm 31.6$ (mean $\pm \mathrm{SD}$ ) per sample (Table 2). In dry season, we found 464 larvae $(38.7 \pm 34.7)$ and 363 larvae $(30.3 \pm 28.0)$ in rainy season. Estimated richness was higher in dry season $(14.1 \pm 8.4$; mean \pm confidence interval), followed by fall-water $(12.2 \pm 5.8)$, and rainy seasons $(11.1 \pm 8.4)$. There was significant difference in mayflies abundance with relation to season (ANOVA

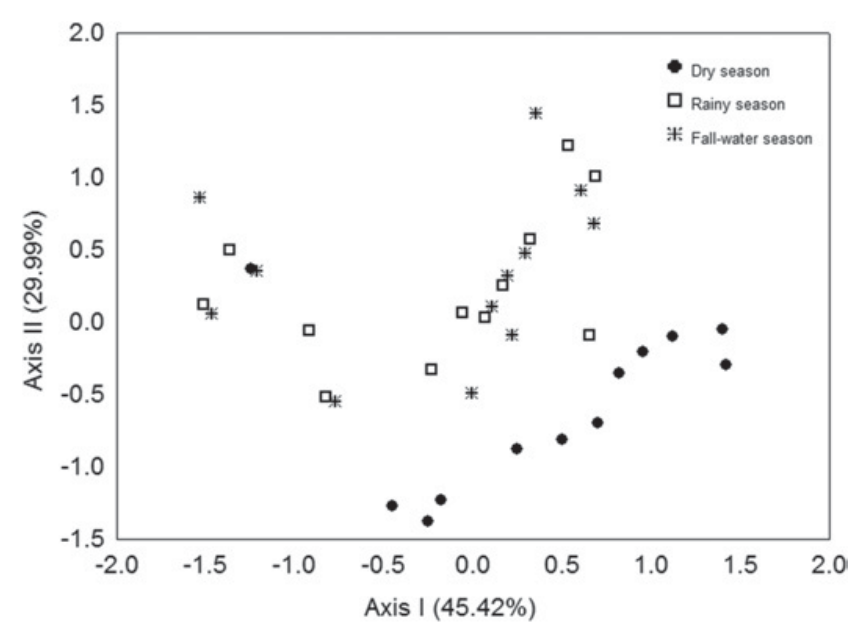

Fig. 2. PCA showing similarity of sampling sites according to stream physicochemistry and HII in the basin of Rio Suiá-Missu, along three seasons (2007-2008), Mato Grosso.

repeated measure $(N=12$, d.f. $=2)=7.277 ; P=0.026)$, restricted between fall-water and rainy (Wilcoxon $=6.500$; $z=2.356$; and $P=0.018$ ) (Fig. 3). Mayflies estimated richness have shown no difference among seasons (ANOVA repeated measure $(N=12$, d.f. $=2)=0.933 ; P=0.627)$.

Caddisfly larvae belonged to seven families, 17 genera, and 45 species/morphospecies. Abundance was higher in average in fall-water $(3.1 \pm 1.1)$, followed by dry $(2.5 \pm 1.1)$, and rainy seasons $(1.6 \pm 1.2)$. There was significant differences in abundance and estimated richness among seasons (ANOVA repeated measure $(N=12$, d.f. $=2)=8.979 ; P=0.011$, and ANOVA repeated measure $(N=12$, d.f. $=2)=12.046 ; P=0.002$, respectively $)$. We identify that fall-water was more abundant than rainy season $($ Wilcoxon $=4.000 ; z=2.746 ; P=0.006$ ), while fallwater and dry seasons were richer than rainy season (Wilcoxon $=0.000 ; z=2.934 ; P=0.003$ and Wilcoxon $=$ $1.500 ; z=2.310 ; P=0.021$, respectively) (Fig. 3).

Accordingly, there were significant relationships among total species richness and the first PCA axes, showing decrease in species number with enhancement of channel width, depth, and increase of water temperature and decrease of turbidity (Fig. 4). Caddisflies species richness showed the same pattern observed for the general community $\left(r^{2}=0.128 ; P=0.031 ; y=4.889-1.912^{*} x\right)$, 
Table 2. Degrees of concordance between DCA scores (for each taxon alone and combined dataset) and PCA scores (for environmental variables) calculated for the environmental variables. $m^{2}$ statistic is below and significance is above main diagonal.

\begin{tabular}{lcccc}
\hline & Ephemeroptera & Trichoptera & General & Environment \\
\hline Ephemeroptera & & $\mathbf{0 . 0 1 1}$ & - & 0.072 \\
Trichoptera & $\mathbf{0 . 3 8 7}$ & - & - & 0.115 \\
General & - & - & $\mathbf{0 . 4 3 4}$ & $\mathbf{0 . 0 0 1}$ \\
Environment & 0.309 & 0.275 & $\mathbf{0 . 4 5}$ \\
\hline
\end{tabular}

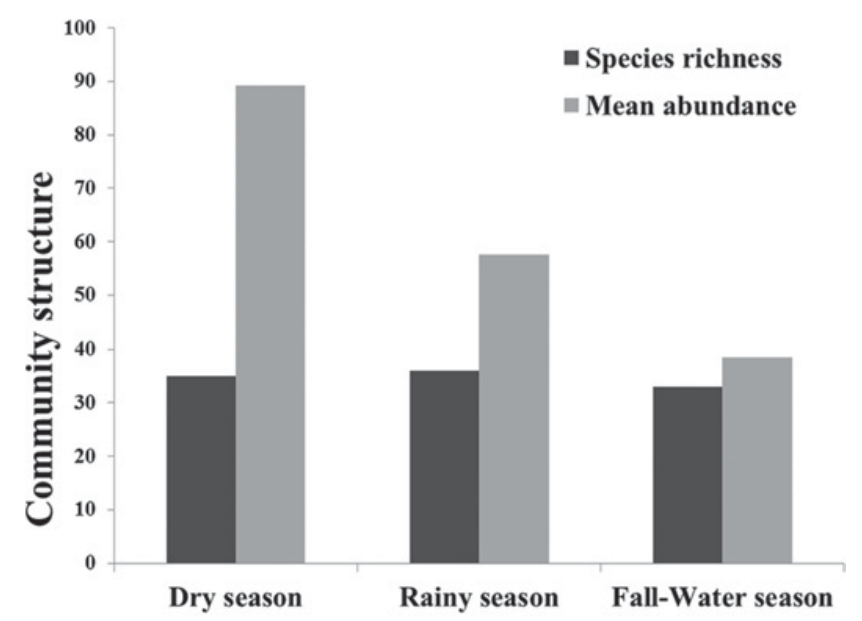

Fig. 3. Seasonal distribution of general species richness and abundance of Trichoptera and Ephemeroptera along three seasons (2007-2008), in Suiá-Missu River basin, Mato Grosso.

whereas mayflies did not have relationships with these environmental gradients $(P>0.05)$.

DCA did not indicate a clear separation of sampling sites according to seasons, in the first or second axis (Fig. 5). The ANOVA results corroborate these results, indicating no differences in species composition among the three seasons both the first (ANOVA: $F_{(2,32)}=0.300$; $P=0.743$ ) as well as in the second axis (ANOVA: $\left.F_{(2,32)}=0.036 ; P=0.965\right)$.

\section{Concordance}

Procrustes showed a high concordance between assemblages of mayflies and caddisflies during fall-water and rainy seasons $\left(m^{2}=0.66, P<0.01 ; m^{2}=0.56, P<0.05\right.$, respectively). Contrasting our expectative, in dry season there was no concordance between the assemblages $\left(m^{2}=0.39, P=0.25\right)$. We found a concordance between environmental variables and the two taxa analyzed separately only during fall-water (Fig. 6). We also found high congruence when both groups were analyzed jointly against environmental seasonality $\left(m^{2}=0.43, P<0.05\right.$, Fig. 6). When we analyzed the temporal concordance using each seasons as replicate there were both concordance between caddisflies and mayflies, and between the species composition of both orders and the environment variables (Table 2). Results for concordance without seasonal variation were less representative than when we consider the seasons separately, showing the importance in

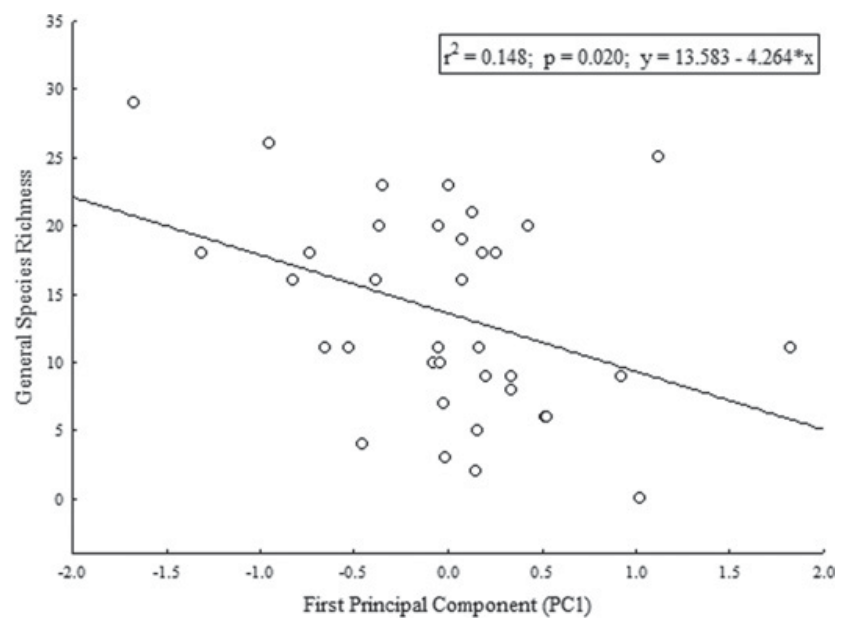

Fig. 4. Relationships of general species richness and the first Principal Component of environmental variation in three seasons (2007-2008), in Suiá-Missu River basin, Mato Grosso.

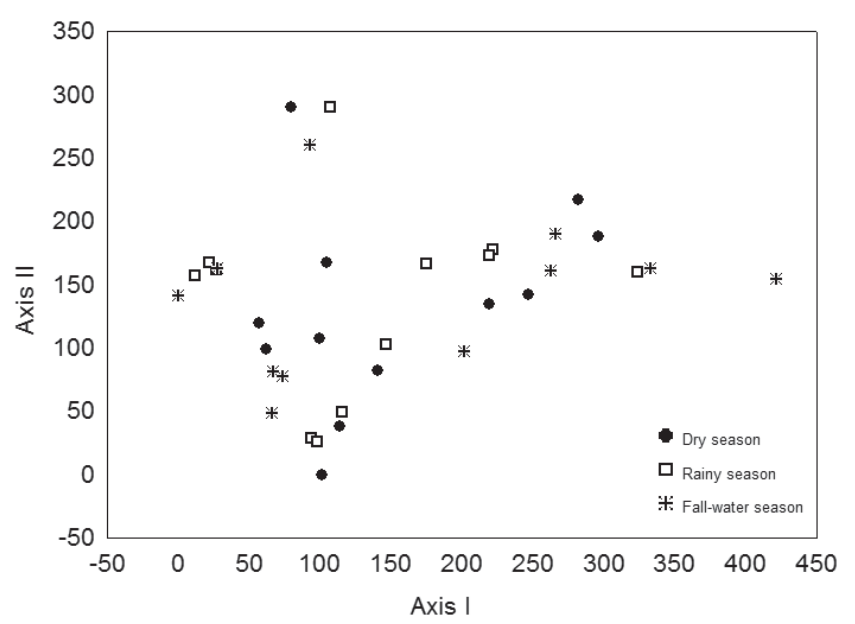

Fig. 5. DCA sampling sites according to species composition along three seasons (2007-2008), basin of Rio Suiá-Missu, Mato Grosso.

considering demographic fluctuation and seasonality for considerations about concordance pattern.

\section{Discussion}

Seasonal rainfall is a major determinant of changes in several environmental variables in freshwater ecosystems in Brazilian Cerrado, for example, $\mathrm{pH}$, water temperature (Melo and Froehlich, 2001; Bini et al., 2007), turbidity, conductivity, water flow, and discharge can be affected by 


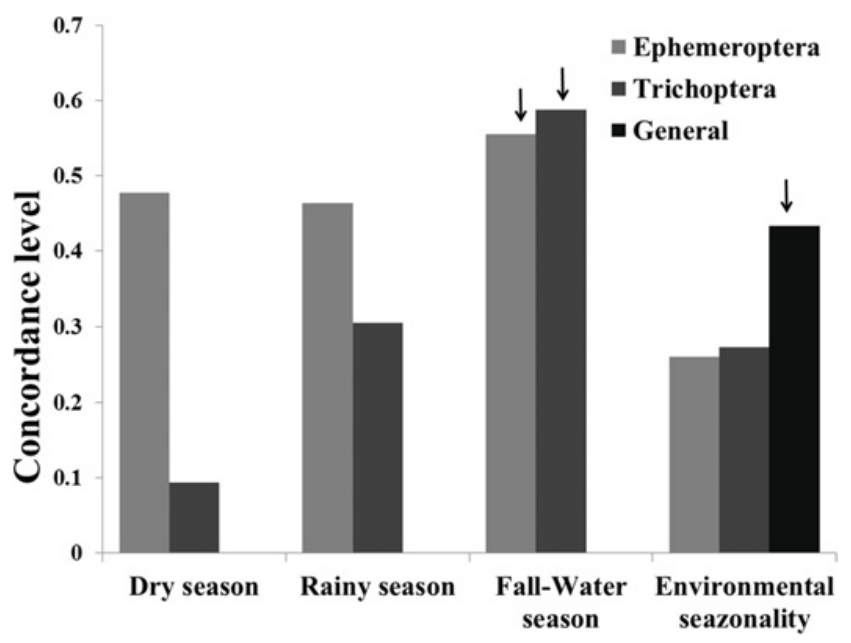

Fig. 6. Concordance patterns for caddisflies and mayflies and the environment along three seasons and environmental seasonality; concordance for composite community dataset (caddsflies and mayflies) and environmental seasonality along three seasons (2007-2008), in Suiá-Missu River basin, Mato Grosso. The black arrows indicate significant concordance according to a $P$-level of 0.05 .

rain. During our study an unusual period of drought in December caused by delay of rainfall, reflected in low variation in some environmental variables.

The concordance found between Ephemeroptera and Trichoptera assemblages in fall-water and rainy seasons can reflect the sensibility of both orders to rain action. Although they present adaptations to fix themselves in the substratum, like dorsoventrally flattened body and claws with denticles and setae in Ephemeroptera (Domínguez et al., 2006), and line mooring construction and silk refuges in Trichoptera (Wiggins, 1996), they are sensible to rains due to the increase and turbulence of water, that often carrys them downstream (Bispo et al., 2001; Melo et al., 2003). Disturbance effects caused by increase of flow have been shown in experiments in streams communities of New Zealand (Melo et al., 2003). The authors showed decrease of species density and diversity in the first weeks after disturbance. According to the Flood Pulse Concept, proposed by Junk et al. (1989), high flow caused by water of the rains can cause catastrophic events for many organisms, being like a periodical reset in physics and biotic environment, reflecting in the homogenization of available substrata and fauna in this season of years, reflecting also in dominant species distribution.

Another factor that probably contributed to the concordance of these orders is that aquatic insects present behavioral responses that allow them to escape from negative effects of disturbance, through lateral migrations to search refuge preceding the first rains (Hynes, 1970; Junk et al., 1989). Moreover, reproduction is adjusted to rainy season, in which they emerge, reproduce and oviposit, preferring substrata protected from fast flow (Brittain, 1982), and running from the period of greater hydrological instability. These kinds of behaviors happening in synchrony between both orders probably contributed to our results. Heino et al. (2003) agree that concordant patterns verified in fall-water season can be related to morphological, physiological adaptations, and especially, behavioral adaptations of these insects to hydrological instability.

In a previous study, Heino (2002) found a strong relationship between both species richness of dragonflies, macrophytes and fish and species richness and richness of the community as a whole. However, same author reports a negative correlation between species richness of Plecoptera and other organisms, because stoneflies have different requirements for water temperature and dissolved oxygen. In a second study, Heino et al. (2003) found low concordance in species richness of larvae from four groups in headwater streams (Ephemeroptera, Trichoptera, Plecoptera, and Chironomidae) in Finland, other studies often found low concordance in the structure and species richness in freshwater ecosystems, especially at small spatial scales (e.g. within basin Allen et al., 1999; Paavola et al., 2003; Tolonen et al., 2005). Low concordance can arise between similar-sized organisms, such as different groups of aquatic insects, because of specific requirements to use of the environment. For instance, this phenomenon can be caused by distinct dietary and physiological requirements, differences in substrate choice, and resistance to flow disturbance (Heino et al., 2003).

Environmental factors have been suggested as the main factor responsible for structuring freshwater communities (Landeiro et al., 2012; Roque et al., 2012). The biological processes that influence taxa establishment and their persistence in these environments are, often, manifested most strongly at the regional scale, for instance because hydrology of the catchments and inherent geomorphology are pointed out to be the main controlling factor of environmental disturbance at local scale. Considering the seasonal variations, only in the fall-water season Ephemeroptera and Trichoptera were congruent with environmental variables.

Despite evidences suggesting that deterministic and stochastic processes drive variations in freshwater community composition and congruence (Siqueira et al., 2012), evaluations of the prevalence of these processes along temporal and environmental gradients including the effects of disturbances could have promising information, and need to be explicitly incorporated into the partitions variance analysis.

However, other characteristics of community seem to contribute with greater concordances in diversity patterns, as reported for taxa with similar body size (Allen et al., 1999), more narrow taxonomic (niche conservatism), and within functional groups (Siqueira et al., 2012).

In the same way, according to Grenouillet et al. (2008), the concordance between macroinvertebrates, diatomaces and fish can be explained by trophic interactions and convergences in organism histories. Once, non-related organisms with similar response to the environment can have similar patterns of distribution on aquatic ecosystems. However, we cannot affirm that environmental variables can be replaced by mayfly and caddisfly sampling once the 
correlation was low $(r=0.434$, strong correlations $>0.70$, obtained in Heino, 2010).

It shows one more time, that independently of each other, both orders are sensible to changes in water quality and highlight the importance of these groups to conservation planning and water quality biomonitoring (Landeiro et al., 2012). Corroborating our result, Couceiro et al. (2010) analyzing indicator species, found that four taxa of Ephemeroptera and ten of Thichoptera were associated with non-impacted streams, and no taxa indicated the impacted ones. The greater concordance between both taxa and environmental variables may indicate that they are complementary and need to be sampled together if environmental changes have to be detected. Nevertheless, we cannot affirm that only one order could be sampled due to the greater results found when we used both orders in analysis. If indicator groups and surrogates are relevant to freshwater biodiversity conservation more investments, deep and wide studies focusing on temporal and spatial variation have to be made, mainly addressing reduction of costs by use of high-order taxonomic resolution and crosstaxon congruence (Heino, 2010).

We conclude that environmental variations in streams resulted from temporal changes (season of the year) directly influence the patterns of mayflies and caddisflies distributions, though they have adaptations for rain effect. The differences in concordance between Ephemeroptera and Trichoptera found according to the seasons of the years, the fact that both orders agree with environmental variables only in the fall-water season, and less representativeness of our results when seasons were analyzed together make us support the fact that the hydrological cycle could be a driver of changes in species composition, as predicted by the Flood Pulse Concept.

Acknowledgements. We thank Frederico Falcão Salles and Ana Maria Oliveira Pes for identification of mayfly and caddisfly larvae, respectively. Ully M. Pozobom Costa did the limnological analysis. We thank all staff of Laboratório de Entomologia of Nova Xavantina, University of State of Mato Grosso UNEMAT, for laboratory and field help. We also thank support from PROCAD/CAPES no. 109/2007 and Conselho Nacional de Pesquisa e Desenvolvimento - CNPq (no. 520268/2005-9) received by the project's coordinator Ladislau A. Skorupa (EMBRAP-Meio Ambiente). DSN received a fellowship of Coordenação de Aperfeiçoamento de Pessoa de Nível Superior - CAPES and YS of Fundo de Amparo à Pesquisa do Pará - FAPESPA. We also thank Dr. Frederico Falcão Salles and anonymous referees for their helpful comments on an earlier version of the manuscript.

\section{References}

Allen A.P., Whittier T.R., Kaufmann P.R., Larsen D.P., O'Connor R.J., Hughes R.M., Stemberger R.S., Dixit S.S., Brinkhurst R.O., Herlihy A.T. and Paulsen S.G., 1999. Concordance of taxonomic richness patterns across multiple assemblages in lakes of the northeastern United States. Can. J. Fish Aquat. Sci., 56, 739-747.
Angrisano E.B. and Korob P.G., 2001. Trichoptera. In: Fernández H.R. and Domínguez E. (eds.), Guia para la identificacion de los artrópodos bentônicos sudamericanos, Editorial Universitaria de Tucumám, Tucamám, 55-92.

Bini L.M., Vieira L.C.G., Machado J. and Velho L.F.M., 2007. Concordance of species composition patterns among microcrustaceans, rotifers and testate amoebae in a shallow pond. Int. Rev. Hydrobiol., 92, 9-22.

Bini L.M., Silva L.C.F., Velho L.F.M., Bonecker C.C. and Lansac-Toha F.A., 2008. Zooplankton assemblage concordance patterns in Brazilian reservoirs. Hydrobiologia, 598, 247-255.

Bispo P.C., Oliveira L.G., Crisci-Bispo V.L. and Silva M.M., 2001. A pluviosidade como fator de alteração da entomofauna bentônica (Ephemeroptera, Plecoptera e Trichoptera) em córregos do Planalto Central do Brasil. Acta Limnol. Bras., 13, 1-9.

Bowman M.F., Ingram R., Reid R.A., Somers K.M., Yan N.D., Paterson A.M., Morgan G.E. and Gunn J.M., 2008. Temporal and spacial concordance in community composition of phytoplakton, zooplakton, macroinvertebrate, crayfish, and fish on Precambrian Shield. Can. J. Fish Aquat. Sci., 65, 919-932.

Brittain J.E., 1982. Biology of mayflies. Annu. Rev. Entomol., 27, 119-147.

Cameron S.E., Williams K.J. and Mitchell D.K., 2008. Efficiency and concordance of alternative methods for minimizing opportunity costs in conservation planning. Conserv. Biol., 22, 886-896.

Carvalho N.D.O., Cafe F.A., Mota G.D.O., Franco H.C.D.B. and Braga A., 2004. Assessment of the sedimentation in the reservoirs of the Belo Monte hydroelectric complex, Xingu River, Brazil. In: Proceedings of the Ninth International Symposium on River Sedimentation, Vols 1-4, 233-242.

Colwell R.K., 2005. EstimateS: statistical estimation of species richness and shared species from samples. Version 7.5.

Couceiro S.R.M., Hamada N., Forsberg B.R. and PadovesiFonseca C., 2010. Effects of anthropogenic silt on aquatic macroinvertebrates and abiotic variables in streams in the Brazilian Amazon. J. Soils Sediments, 10, 89-103.

DeChaine E.G. and Martin A.P., 2005. Historical biogeography of two alpine butterflies in the Rocky Mountains: broad-scale concordance and local-scale discordance. J. Biogeogr., 32, 1943-1956.

Domínguez E., Molineri C., Pescador M.L., Hubbard M. and Nieto C., 2006. Ephemeroptera of South America, Pensoft Publ., Moscow, 646 p.

Faith D.P., 2003. Environmental diversity (ED) as surrogate information for species-level biodiversity. Ecography, 26, 374-379.

Gauch H.G., 1982. Multivariate Analysis in Community Ecology, Cambridge University Press, Cambridge, 312 p.

Grenouillet G., Brosse S., Tudesque L., Lek S., Baraillé Y. and Loot G., 2008. Concordance among stream assemblages and spatial autocorrelation along a fragmented gradient. Divers Distrib., 14, 592-603.

Heino J., 2002. Concordance of species richness patterns among multiple freshwater taxa: a regional perspective. Biodivers. Conserv., 11, 137-147.

Heino J., 2010. Are indicator groups and cross-taxon congruence useful for predicting biodiversity in aquatic ecosystems?Ecol. Indic., 10, 112-117. 
Heino J. and Mykrä H., 2006. Assessing physical surrogates for biodiversity: Do tributary and stream type classifications reflect macroinvertebrate assemblage diversity in running waters? Biodivers. Conserv., 129, 418-426.

Heino J., Muotka T. and Paavola R., 2003. Determinants of macroinvertebrate diversity in headwater streams: regional and local influences. J. Animal Ecol., 72, 425-434.

Heino J., Paavola R., Virtanen R. and Muotka T., 2005. Searching for biodiversity indicators in running waters: do bryophytes, macroinvertebrates, and fish show congruent diversity patterns? Biodivers. Conserv., 14, 415-428.

Hynes H.B.N., 1970. The ecology of stream insects. Annu. Rev. Entomol., 15, 25-42.

Jackson D.A., 1995. Protest - a Procrustean randomization test of community environment concordance. Ecoscience, 2, 297303.

Jackson D.A. and Harvey H.H., 1993. Fish and benthic invertebrates: community concordance and community-environment relationships. Can. J. Fish Aquat. Sci., 50, 2641-2651.

Juen L. and De Marco P., 2011. Odonata biodiversity in terrafirme forest streamlets in Central Amazonia: on the relative effects of neutral and niche drivers at small geographical extents. Insect. Conserv. Diver., 4, 265-274.

Junk W.J., Bayley P.B. and Sparks R.E., 1989. The flood pulse concept in river-floodplain systems. In: Dodge D.P. (ed.), Proceedings of the International Large River Symposium, $110-127$.

Landeiro V.L., Bini L.M., Melo A.S., Pes A.M.O. and Magnusson W.E., 2012. The roles of dispersal limitation and environmental conditions in controlling caddisfly (Trichoptera) assemblages. Freshwater Biology, 57, 15541564.

Melo A.S. and Froehlich C.G., 2001. Macroinvertebrates in neotropical streams: richness patterns along a catchment and assemblage structure between 2 seasons. J. N. Am. Benthol. Soc., 20, 1-16.

Melo A.S., Niyogi D.K., Matthaei C.D. and Townsend C.R., 2003. Resistance, resilience, and patchiness of invertebrate assemblages in native tussock and pasture streams in New Zealand after a hydrological disturbance. Can. J. Fish Aquat. Sci., 60, 731-739.

Monaghan K.A. and Soares A.M.V.M., 2010. The bioassessment of fish and macroinvertebrates in a MediterraneanAtlantic climate: habitat assessment and concordance between contrasting ecological samples. Ecol. Indic., 10, 184-191.

Nessimian J.L., Venticinque E.M., Zuanon J., De Marco P. Jr., Gordo M., Fidelis L., Batista J.D. and Juen L., 2008. Land use, habitat integrity, and aquatic insect assemblages in Central Amazonian streams. Hydrobiologia, 614, 117-131.

Nogueira D.S., Cabette H.S.R. and Juen L., 2011. Estrutura e composição da comunidade de Trichoptera (Insecta) de rios e áreas alagadas da Bacia do rio Suiá-Missu, Mato Grosso, Brasil, Iheringia. Sér. Zool., 101, 173-180.

Oksanen J., Blanchet F.G., Kindt R., Legendre P., Minchin P.R., O'Hara R.B., Simpson G.L., Solymos P., Stevens M.H.H. and Wagner H., 2011. Vegan: Community Ecology Package. $\mathrm{R}$ package version 2.0-2. http://CRAN.R-project.org/ package $=$ vegan .

Olden J.D., Jackson D.A. and Peres-Neto P.R., 2001. Spatial isolation and fish communities in drainage lakes. Oecologia, 127, 572-585.
Paavola R., Muotka T., Virtanen R., Heino J. and Kreivi P., 2003. Are biological classifications of headwater streams concordant across multiple taxonomic groups?Freshwater Biol., 48, 1912-1923.

Paszkowski C.A. and Tonn W.M., 2000. Community concordance between the fish and aquatic birds of lakes in northern Alberta, Canada: the relative importance of environmental and biotic factors. Freswater Biol., 43, 421-437.

Pes A.M.O., Hamada N. and Nessimian J.L., 2005. Chaves de identificação de larvas para famílias e gêneros de Trichoptera (Insecta) da Amazônia Central, Brasil. Revta Bras. Ent., 49, 181-204.

Ratter J.A., Askew G.P., Montgomery R.F. and Gifford D.R., 1978. Observations on the vegetation of northeastern Mato Grosso II. Forest and Soils of the Rio Suiá-Missu area. R. Soc. Lond., 293, 191-208.

R Development Core Team, 2011. R: A Language and Environment for Statistical Computing, R Foundation for Statistical Computing, Vienna, Austria.

Riva A.L.M., Fonseca L.F.L. and Hasenclever L., 2007. Instrumentos econômicos e financeiros para a conservação ambiental no Brasil: Uma análise do estado da arte no Brasil e no Mato Grosso, desafios e perspectivas, Instituto Socioambiental - ISA, São Paulo, 138 p.

Roque F.O., Lima D.V.M., Siqueira T., Vieira L.J.S., Stefanes M. and Trivino-Strixino S., 2012. Concordance between macroinvertebrates communities and the typological classification of White and clear-water streams in western Brazilian Amazonia. Biota Neotropical, 12, 83-92.

Rosenberg D.M. and Resh V.H., 1993. Introduction to freshwater biomonitoring and benthic macroinvertebrates. In: Rosenberg D.M. and Resh V.H. (eds.), Freshwater Biomonitoring and Benthic Macroinvertebrates, Chapman and Hall, New York, 1-9.

Shimano Y., Cabette H.S.R., Salles F.F. and Juen L., 2010. Composição e distribuição da fauna de Ephemeroptera (Insecta) em área de transição Cerrado-Amazônia, Brasil. Iheringia, 100, 301-308.

Siqueira T., Bini L.M., Roque F.O. and Correnie K., 2012. A metacommunity framework for enhancing the effectiveness of biological monitoring strategies. Plos One, 7, 1-12.

Strahler H.N., 1957. Quantitative analysis of watershed geomorphology. Am. Geophys. Union Trans., 38, 913-920.

Tolonen K.T., Holopainen I.J., Hamalainen H., RahkolaSorsa M., Ylostalo P., Mikkonen K. and Karjalainen J., 2005. Littoral species diversity and biomass: concordance among organism groups and the effects of environmental variables. Biodivers. Conserv., 14, 961-980.

Vannote R.L., Minshall G.W., Cummins K.W., Sedell J.R. and Cushing C.E., 1980. The river continuum concept. Can. J. Fish Aquat. Sci., 37, 130-137.

Wiggins G.B., 1996. Larvae of the North American Caddisfly Genera (Trichoptera), University of Toronto Press, Toronto, $457 \mathrm{p}$.

Wiggins G.B. and Mackay R.J., 1978. Some relationships between systematics and trophic ecology in Neartic aquatic insects, with special references to Trichoptera. Ecology, 59, 1211-1220.

Zar J.H., 1999. Biostatistical Analysis, Prentice-Hall, Englewood Cliffs, NJ, 960 p. 
Appendix 1. Mean and standard deviation for species abundance of mayflies per stream site, during the sampling period (2007-2008) in the basin of Rio Suiá-Missu, Mato Grosso.[colent =7].

\begin{tabular}{|c|c|c|c|c|c|c|}
\hline \multirow[b]{2}{*}{ Especies } & \multicolumn{2}{|c|}{ Fall-water season } & \multicolumn{2}{|c|}{ Dry season } & \multicolumn{2}{|c|}{ Rainy season } \\
\hline & Mean & SD & Mean & SD & $\overline{\text { Mean }}$ & SD \\
\hline Amanahyphes saguassu (Salles \& Molineri, 2006) & 1.583 & 2.539 & 0.417 & 0.669 & 0.417 & 1.443 \\
\hline Americabaetis alphus (Lugo-Ortiz \& McCafferty, 1995) & 0.250 & 0.866 & 0.333 & 0.651 & 0.417 & 1.443 \\
\hline Apobaetis fuizai (Salles \& Lugo-Ortiz, 2002) & 0.000 & 0.000 & 0.000 & 0.000 & 0.083 & 0.289 \\
\hline Askola sp. & 0.083 & 0.289 & 0.500 & 1.000 & 0.167 & 0.389 \\
\hline Asthenopus cf. curtus (Hagen, 1861) & 4.667 & 8.532 & 0.500 & 1.732 & 0.417 & 0.793 \\
\hline Aturbina sp.n. & 0.500 & 1.000 & 0.417 & 0.793 & 0.667 & 1.155 \\
\hline Aturbina georgei (Lugo-Ortiz \& McCafferty, 1996) & 0.167 & 0.389 & 0.667 & 1.155 & 0.833 & 2.290 \\
\hline Brasilocaenis irmeli (Puthz, 1975) & 0.417 & 1.165 & 0.000 & 0.000 & 0.000 & 0.000 \\
\hline Brasilocaenis sp. & 1.833 & 4.840 & 0.083 & 0.289 & 0.167 & 0.577 \\
\hline Caenis cuniana (Froehlich, 1969) & 3.167 & 5.060 & 1.500 & 2.876 & 8.250 & 17.705 \\
\hline Caenis fitkaui (Malzacher, 1986) & 0.500 & 1.446 & 0.500 & 1.243 & 1.583 & 4.010 \\
\hline Caenis pfluggelderi (Malzacher, 1990) & 0.917 & 1.311 & 0.333 & 0.651 & 0.000 & 0.000 \\
\hline Callibaetis sp. 1 & 3.750 & 6.468 & 1.667 & 2.640 & 3.167 & 4.648 \\
\hline Callibaetis sp. 2 & 0.750 & 1.865 & 1.083 & 3.753 & 1.000 & 3.162 \\
\hline Campsurus spp. & 4.333 & 6.199 & 2.250 & 2.864 & 3.333 & 6.257 \\
\hline Campylocia sp. & 0.583 & 1.730 & 0.583 & 1.443 & 0.167 & 0.389 \\
\hline Cloeodes auwe (Salles \& Batista, 2004) & 0.167 & 0.577 & 0.167 & 0.577 & 0.583 & 2.021 \\
\hline Cloeodes sp. & 0.000 & 0.000 & 0.083 & 0.289 & 0.000 & 0.000 \\
\hline Coryphorus aquilus (Peters, 1981) & 0.417 & 0.900 & 0.333 & 0.492 & 0.417 & 0.793 \\
\hline Cryptonympha copiosa (Lugo-Ortiz \& McCafferty, 1998) & 1.750 & 3.441 & 0.667 & 1.231 & 1.333 & 1.923 \\
\hline Farrodes sp. & 0.750 & 2.301 & 1.417 & 2.906 & 0.167 & 0.389 \\
\hline Fittkaulus sp. & 4.250 & 7.829 & 3.500 & 4.442 & 1.167 & 2.329 \\
\hline Hagenulopsis sp. & 0.083 & 0.289 & 0.083 & 0.289 & 0.000 & 0.000 \\
\hline Harpagobaetis gulosus (Mol, 1986) & 0.083 & 0.289 & 0.000 & 0.000 & 0.000 & 0.000 \\
\hline Hydrosmilodon gilliesae (Thomas \& Peru, 2004) & 0.167 & 0.389 & 1.000 & 2.296 & 0.083 & 0.289 \\
\hline Michophebia surinamenses (Savage \& Peters, 1983) & 0.667 & 2.015 & 0.167 & 0.389 & 0.167 & 0.389 \\
\hline Microphlebia sp. & 1.917 & 3.528 & 3.250 & 6.538 & 0.167 & 0.577 \\
\hline Miroculis sp. 1 & 0.917 & 2.875 & 2.417 & 5.931 & 0.500 & 1.168 \\
\hline Miroculis sp. 2 & 0.917 & 1.379 & 2.667 & 4.638 & 0.417 & 0.900 \\
\hline Paracloeodes binodulus (Lugo-Ortiz \& McCafferty, 1996) & 0.000 & 0.000 & 0.000 & 0.000 & 0.167 & 0.577 \\
\hline Paramaka convexa (Spieth, 1943) & 0.000 & 0.000 & 0.083 & 0.289 & 0.000 & 0.000 \\
\hline Simothraulopsis sp. & 3.500 & 4.719 & 3.667 & 5.466 & 1.583 & 2.429 \\
\hline Thraulodes cochunaensis (Dominguez, 1987) & 0.000 & 0.000 & 0.500 & 1.243 & 0.000 & 0.000 \\
\hline Traverhyphes sp. 1 & 0.167 & 0.389 & 0.250 & 0.622 & 0.083 & 0.289 \\
\hline Traverhyphes sp. 2 & 0.250 & 0.866 & 0.000 & 0.000 & 0.000 & 0.000 \\
\hline Tricorythodes hiemalis (Molineri, 2001) & 1.250 & 3.720 & 1.667 & 4.008 & 0.417 & 1.165 \\
\hline Tricorythodes sp. 1 & 0.083 & 0.289 & 0.167 & 0.389 & 0.250 & 0.622 \\
\hline Tricorythodes sp. 2 & 0.000 & 0.000 & 0.000 & 0.000 & 0.083 & 0.289 \\
\hline Tricorythopsis $\mathrm{sp}$. & 0.083 & 0.289 & 0.083 & 0.289 & 0.000 & 0.000 \\
\hline Ulmeritoides flavopedes (Spieth, 1943) & 2.250 & 3.980 & 2.833 & 4.282 & 1.583 & 3.260 \\
\hline Waltzoyphius roberti (Thomas \& Peru, 2002) & 0.917 & 1.564 & 0.500 & 1.000 & 0.333 & 0.492 \\
\hline Zelusia principalis (Lugo-Ortiz \& McCafferty, 1998) & 0.000 & 0.000 & 2.333 & 7.463 & 0.083 & 0.289 \\
\hline
\end{tabular}


Appendix 2. Mean and standard deviation for species abundance of caddisflies during the sampling period (2007-2008) in the basin of Rio Suiá-Missu, Mato Grosso.

\begin{tabular}{|c|c|c|c|c|c|c|}
\hline \multirow[b]{2}{*}{ Especies } & \multicolumn{2}{|c|}{ Fall-water season } & \multicolumn{2}{|c|}{ Dry season } & \multicolumn{2}{|c|}{ Rainy season } \\
\hline & Mean & SD & Mean & $\mathrm{SD}$ & Mean & $\mathrm{SD}$ \\
\hline Amazonatolica hamadea (Holzenthal \& Pes, 2004) & 0.250 & 0.866 & 0.167 & 0.577 & 0.083 & 0.289 \\
\hline Amphoropsyche sp.1 & 0.250 & 0.622 & 0.000 & 0.000 & 0.000 & 0.000 \\
\hline Amphoropsyche sp.2 & 0.083 & 0.289 & 0.167 & 0.389 & 0.000 & 0.000 \\
\hline Amphoropsyche sp. 3 & 0.083 & 0.289 & 0.000 & 0.000 & 0.000 & 0.000 \\
\hline Cernotina sp. 1 & 0.000 & 0.000 & 0.083 & 0.289 & 0.000 & 0.000 \\
\hline Cernotina sp. 2 & 1.000 & 1.706 & 0.917 & 1.730 & 0.500 & 0.905 \\
\hline Chimarra sp. 1 & 0.083 & 0.289 & 1.083 & 2.021 & 0.000 & 0.000 \\
\hline Chimarra sp. 2 & 0.000 & 0.000 & 0.333 & 0.778 & 0.000 & 0.000 \\
\hline Cyrnellus sp.1 & 0.250 & 0.622 & 0.333 & 0.651 & 0.000 & 0.000 \\
\hline Cyrnellus sp.2 & 0.333 & 1.155 & 0.083 & 0.289 & 0.333 & 0.888 \\
\hline Cyrnellus sp.3 & 0.000 & 0.000 & 0.083 & 0.289 & 0.000 & 0.000 \\
\hline Leptonema amazonense (Flint, 1978) & 0.083 & 0.289 & 0.000 & 0.000 & 0.000 & 0.000 \\
\hline L. maculatum (Mosely, 1933) & 1.000 & 2.486 & 3.583 & 8.372 & 0.000 & 0.000 \\
\hline L. sparsum (Ulmer, 1905) & 22.333 & 63.066 & 4.333 & 5.990 & 4.167 & 8.922 \\
\hline Macronema spp. & 4.083 & 4.358 & 2.500 & 2.844 & 1.083 & 2.109 \\
\hline Macrostemum hyalinum (Pictet, 1836) & 0.000 & 0.000 & 0.083 & 0.289 & 0.000 & 0.000 \\
\hline Macrostemum sp.1 & 0.167 & 0.577 & 0.667 & 2.309 & 0.083 & 0.289 \\
\hline Macrostemum sp.2 & 5.833 & 18.115 & 0.667 & 1.557 & 0.500 & 1.732 \\
\hline Marilia sp.1 & 0.417 & 1.443 & 0.250 & 0.866 & 0.000 & 0.000 \\
\hline Marilia sp. 3 & 0.167 & 0.389 & 0.000 & 0.000 & 0.083 & 0.289 \\
\hline Nectopsyche sp.1 & 0.000 & 0.000 & 0.083 & 0.289 & 0.000 & 0.000 \\
\hline Nectopsyche sp. 2 & 0.167 & 0.389 & 0.500 & 0.798 & 0.083 & 0.289 \\
\hline Nectopsyche sp.3 & 0.083 & 0.289 & 0.167 & 0.389 & 0.000 & 0.000 \\
\hline Nectopsyche sp.4 & 0.083 & 0.289 & 0.083 & 0.289 & 0.000 & 0.000 \\
\hline Nectopsyche sp.5 & 0.083 & 0.289 & 0.000 & 0.000 & 0.000 & 0.000 \\
\hline Nectopsyche sp.6 & 0.083 & 0.289 & 0.000 & 0.000 & 0.000 & 0.000 \\
\hline Oecetis sp.1 & 0.417 & 0.669 & 0.000 & 0.000 & 0.083 & 0.289 \\
\hline Oecetis sp.2 & 1.083 & 0.793 & 0.000 & 0.000 & 0.000 & 0.000 \\
\hline Oecetis sp. 3 & 1.417 & 2.503 & 0.167 & 0.389 & 0.083 & 0.289 \\
\hline Oecetis sp.4 & 0.750 & 1.055 & 0.083 & 0.289 & 0.250 & 0.622 \\
\hline Oecetis sp.5 & 1.583 & 5.178 & 0.000 & 0.000 & 0.000 & 0.000 \\
\hline Oecetis sp.6 & 0.167 & 0.389 & 0.000 & 0.000 & 0.000 & 0.000 \\
\hline Oxyethira sp.1 & 0.083 & 0.289 & 0.000 & 0.000 & 0.000 & 0.000 \\
\hline Phylloicus sp.1 & 0.083 & 0.289 & 0.000 & 0.000 & 0.000 & 0.000 \\
\hline Polyplectropus sp.1 & 0.833 & 2.887 & 0.167 & 0.577 & 0.000 & 0.000 \\
\hline Polyplectropus sp. 2 & 0.083 & 0.289 & 0.000 & 0.000 & 0.000 & 0.000 \\
\hline Polyplectropus sp. 3 & 0.083 & 0.289 & 0.000 & 0.000 & 0.083 & 0.289 \\
\hline Smicridea (R.) sp.1 & 0.500 & 1.732 & 0.000 & 0.000 & 0.083 & 0.289 \\
\hline Smicridea (R.) sp. 2 & 0.083 & 0.289 & 0.000 & 0.000 & 0.000 & 0.000 \\
\hline Smicridea $($ S.) truncate (Flint, 1974) & 0.083 & 0.289 & 1.083 & 3.147 & 0.167 & 0.577 \\
\hline Smicridea (S.) sp.2 & 0.667 & 1.775 & 0.583 & 1.730 & 0.000 & 0.000 \\
\hline Smicridea $(S$.$) sp.3$ & 0.000 & 0.000 & 0.333 & 1.155 & 0.417 & 1.443 \\
\hline Smicridea (S.) sp.4 & 0.083 & 0.289 & 0.000 & 0.000 & 0.000 & 0.000 \\
\hline Smicridea (S.) sp.7 & 0.167 & 0.577 & 0.000 & 0.000 & 0.000 & 0.000 \\
\hline Triplectides sp.1 & 0.000 & 0.000 & 0.167 & 0.577 & 0.167 & 0.577 \\
\hline Wormaldia sp.1 & 0.000 & 0.000 & 0.083 & 0.289 & 0.000 & 0.000 \\
\hline
\end{tabular}

